\title{
Development of a loop-mediated isothermal amplification method for detection of Perkinsus spp. in mollusks
}

\author{
Chunyan Feng*, Caixia Wang*, Xiangmei Lin*, Yongning Zhang, Jizhou Lv, \\ Junhua Deng, Xiangfen Yuan, Lin Mei, Shaoqiang Wu**
}

Institute of Animal Quarantine, Chinese Academy of Inspection and Quarantine, Beijing 100029, PR China

\begin{abstract}
Perkinsus is a genus of unicellular protozoan parasite responsible for mass mortality of several commercially valuable mollusks. Surveillance and inspection of its epidemiology in the field calls for convenient and rapid detection methods. Here, a loop-mediated isothermal amplification (LAMP) assay was developed to detect the presence of Perkinsus spp. in mollusks. Specific LAMP primers were designed targeting the conserved internal transcribed spacer 2 (ITS-2) region of the rRNA gene of Perkinsus spp. Using ITS-2 recombinant plasmid as a template, we optimized the LAMP reaction system and conditions and then evaluated the analytical sensitivity and specificity of the assay. The LAMP assay was validated using clam samples collected from coastal areas in eastern China and oysters imported to China and compared with the traditional Ray's fluid thioglycollate culture method (RFTM). Our results showed that the LAMP detection method for Perkinsus was successful. The detection limit was 10 copies of plasmid DNA. Compared to the RFTM assay, the LAMP detection method was more sensitive (56 versus 52 positive out of 60 samples). P. olseni and P. marinus from infected hosts were successfully detected by this method. The LAMP method is rapid, sensitive, and specific for Perkinsus spp. detection, and could be used to screen for perkinsosis both on farms and at ports.
\end{abstract}

KEY WORDS: Perkinsus olseni · Perkinsus marinus · Mollusk · LAMP assay · Ray's fluid thioglycollate medium culture assay $\cdot$ Detection method

\section{INTRODUCTION}

Perkinsosis is a worldwide parasitic disease of mollusks caused by Perkinsus species (Villalba et al. 2004). Among the 6 recognized Perkinsus species, $P$. olseni (also named P. atlanticus) and P. marinus are the primary causes of severe economic losses in a number of shellfisheries (Villalba et al. 2004). Conventional methods for the detection of Perkinsus spp. in oysters and clams include histological observation and pathogenic examination after culture of host tissues by Ray's fluid thioglycollate culture method (RFTM; Ray 1952). Although recommended by the World Organization of Animal Health (OIE) as the 'gold standard' for Perkinsus spp. diagnosis, RFTM is known to lack specificity. Some Perkinsus-like parasites, particularly dinoflagellates, can yield false positive results in the RFTM assay. RFTM is time consuming, taking 4 to $7 \mathrm{~d}$ (Robledo et al. 1998), and therefore a rapid field diagnostic test is needed.

Specificity and sensitivity are the main principles for the establishment of new diagnostic methods. The application of nucleic acid amplification methods combined with sequencing tools has largely overcome the specificity and sensitivity limitations associated with the RFTM assay (Robledo et al. 1998, Yarnall et al. 2000, Park et al. 2005). Having multiple occurrences in the genome of Perkinsus sp., the 
internal transcribed spacer (ITS) regions (including ITS1 and ITS2) have become one of the most frequently adopted gene markers in the determination of genus and species of Perkinsus (Kotob et al. 1999). Audemard et al. (2004) reported that a single cell of $P$. marinus could be detected using a conventional PCR assay targeting the ITS region. Other protocols, such as detection of $P$. marinus in host tissues and environmental samples by polyclonal antibodies, have also been attempted. Results of these methods showed that cross-reaction with several free-living, phototrophic, and parasitic dinoflagellate species was unavoidable (Dungan \& Roberson 1993, Bushek et al. 2002).

Loop-mediated isothermal amplification (LAMP) is a novel nucleic acid amplification method that amplifies a DNA template under isothermal conditions. This method employs a Bacillus stearothermophilus (Bst) DNA polymerase and a set of 4 specially designed primers that recognize a total of 6 distinct regions on the target DNA sequence. It can amplify the target sequence (either DNA or RNA template) in a very short time with high sensitivity, specificity, and efficiency (Notomi et al. 2000). For these reasons, the LAMP assay has been widely applied in the detection of pathogenic microorganisms (Tatibana et al. 2009), genetically modified ingredients (Fukuta et al. 2004), and tumors (Horibe et al. 2007), as well as in embryo sex identification (Hirayama et al. 2004). In this study, we developed a LAMP assay for the detection of Perkinsus spp.

\section{MATERIALS AND METHODS}

\section{Sample collection}

Live clams Ruditapes philippinarum were collected from farms in the Yellow Sea and East China Sea during the summers of 2010 and 2011. The samples were labeled and shipped to our lab on ice. Suspected Perkinsus marinus-infected oysters were imported from Australia in May 2011 and August 2012; these samples were first inspected by PCR and sent to our lab for confirmation by the Guangdong Entry-Exit Inspection and Quarantine Bureau, PR China.

\section{Parasite-infected tissue controls}

The status of Bonamia ostreae-infected oysters was confirmed by PCR and subsequent endonuclease digestion assay (OIE 2012a). The DNA of Ichthyoph- thirius multifiliis from infected carp was kindly provided by Dr. Xinzhong Chen from the Xiamen EntryExit Inspection and Quarantine Bureau, PR China. Haplosporidium nelsoni-positive oyster Crassostrea gigas samples were collected from coastal areas of the Yellow Sea in northeast China during the routine aquatic parasite surveillance program performed by our lab (unpubl. data).

\section{RFTM performance}

In total, 60 clams were selected using the diagonal method from the collected samples. After shucking, part of the gill was excised and stored at $-20^{\circ} \mathrm{C}$ for later PCR examination. The remaining parts of each clam tissue were cultured separately with RFTM following the methods of Wu et al. (2011). In brief, the remaining clam tissue was homogenized and then placed in fluid thioglycollate medium (Fluka) supplemented with $2.5 \%$ chloromycetin (Amresco) and $1 \%$ nystatin (Amresco). After incubation at 22 to $25^{\circ} \mathrm{C}$ in the dark for $7 \mathrm{~d}$, the pellets were harvested by centrifugation at $1500 \times g(5 \mathrm{~min})$ and further digested in $1 \mathrm{ml}$ of $2 \mathrm{M}$ sodium hydroxide for $2 \mathrm{~h}$. The digested cellular materials were then centrifuged and the pellets were rinsed 3 times with $0.1 \mathrm{M}$ phosphatebuffered saline containing $0.1 \%$ bovine serum albu$\mathrm{min}$. The pellets were suspended in $2 \mathrm{ml}$ of deionized water, and the suspension was mounted onto a glass slide, stained with Lugol's iodine solution according to Choi et al. (1989), and then examined under a light microscope. The presence of hypnospores in each clam was recorded.

\section{DNA extraction}

The DNA of the above excised part of the gill and of each control parasite-infected tissue was isolated using a DNeasy Blood \& Tissue Kit, following the manufacturer's instructions (Qiagen). The total DNA of oysters was isolated in the same manner with excised gill tissue. All DNA isolates were eluted into $50 \mathrm{\mu l}$ elution buffer and stored at $-20^{\circ} \mathrm{C}$ before use.

\section{Construction of recombinant plasmid for positive control}

The $673 \mathrm{bp}$ ITS-2 fragments were amplified from RFTM-positive samples by PCR using the primers PerkITS85 (5'-CCG CTT TGT TTG GAT CCC-3') 
and PerkITS750 (5'-ACA TCA GGC CTT CTA ATG ATG-3'; Casas et al. 2002). The amplified products were purified and cloned into pGEM-T vector (Promega). After sequencing, the sequence information of these amplicons was subjected to BLAST analysis online (http://blast.ncbi.nlm.nih.gov/Blast.cgi).

\section{LAMP performance}

A set of 6 primers ( 2 outer primers, 2 inner primers, and 2 loop primers) was designed to target the conserved ITS-2 region of Perkinsus spp., using the online software Primer Explorer V4 (http:// primerexplorer.jp). The ITS-2 sequence of Perkinsus isolates from China (GenBank accession number FJ841985) was chosen as the reference sequence for primer design. Considering lower dimer formation, less cross-reaction, and higher amplification efficiency, the ultimately selected primer sets were as follows: forward outer primer (F3), TGG ATT TTG GTA TTT CAA AAC GA; backward outer primer (B3), ATG TTT GTA TCG GGA AGA AGA G; forward inner primer (FIP), AGT GCT TAT CGC ACT TCG CTC AAA CTC TCA ACG ATG GAT GC; backward inner primer (BIP), GAT TTG CAG AAT TCC GTG AAC CAG CAC TGA TAT GTA TGT ACA AAG AGG; loop forward primer (LF), TCC TTC ATC GAT TCT CGA GC; loop backward primer (LB), TCA ACG CAT ACT GCA CAA AG.

To acquire an ideal amplification system, we tried different dosages of each ingredient. Betaine (range from 0 to $0.896 \mathrm{M}$ ), $\mathrm{MgSO}_{4}$ (4 to $32 \mathrm{mM}$ ), dNTP (0.4 to $1.6 \mathrm{mM})$, Bst DNA polymerase (1.6 to $20.8 \mathrm{U})$, outer primers $(0.1$ to $0.6 \mu \mathrm{M})$, inner primers $(0.8$ to $2.8 \mu \mathrm{M})$, and loop primers (with or without) were optimized. Turbidity was used as the index for judging quality, and was measured by a Loopamp® real-time turbidimeter (LA-320C, Eiken). Double-distilled water ( $d \mathrm{H}_{2} \mathrm{O}$ ) was used as template in blank controls. The detection limit of the assay was determined by using 10 -fold serial dilutions of plasmid (ranging from $10^{7}$ to $10^{0}$ copies) as template. The results were judged using a parabola chart, an amplification efficiency chart, or a histogram.

To avoid cross reaction with other protozoan parasites and host tissues, DNA from Bonamia ostreae, Haplosporidium nelsoni, Ichthyophthirius multifiliis, and healthy clams was used as templates in the specificity verification of the Perkinsus spp. LAMP assay. To ensure that the developed Perkinsus LAMP assay could work on other Perkinsus species besides $P$. olseni, suspected P. marinus-infected oysters were chosen for LAMP detection. To determine the actual infection status of these samples, PCR amplification of a $P$. marinus sequence combined with histological observation as further performed according to Audemard et al. (2004).

\section{Evaluation of the LAMP assay}

As recommended by OIE, RFTM has been considered the 'gold standard' in the diagnosis of Perkinsus infection. The above 60 clams examined by RFTM were further evaluated by the LAMP assay. Positive plasmid $\left(1.0 \times 10^{6}\right.$ copies $)$ was used as the positive control and healthy clam DNA as the negative control in the LAMP assay. The result of LAMP detection was compared with that of the RFTM assay.

Samples with different results from RFTM and LAMP detection were further examined. As one EcoRI digestion site was found within the targeted DNA sequence of Perkinsus spp., restriction endonuclease EcoRI digestion was carried out. The digestion solution $(20 \mu \mathrm{l})$ consisted of $2 \mu \mathrm{l} 10 \times \mathrm{H}$ Buffer, $15 \mathrm{U}$ EcoRI,

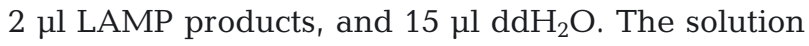
was incubated at $37^{\circ} \mathrm{C}$ for $3 \mathrm{~h}$. The digested solution was visualized under UV light after $2 \%$ agarose gel electrophoresis. The digested LAMP fragments were also sequenced and then analyzed by BLAST online after separation and purification from the gel.

Diagnostic sensitivity (DSe) and diagnostic specificity (DSp) of the LAMP assay were calculated as: $\mathrm{DSe}=\mathrm{TP} /(\mathrm{TP}+\mathrm{FN})$ and $\mathrm{DSp}=\mathrm{TN} /(\mathrm{TN}+\mathrm{FP})(\mathrm{OIE}$ 2012b), where TP is true positive, FN is false negative, TN is true negative, and FP is false positive.

\section{RESULTS}

\section{RFTM culture assay}

The pellets of each sample cultured in the RFTM assay were observed under a light microscope. The hypnospores of Perkinsus were about 10 to $50 \mu \mathrm{m}$ in diameter, bluish-black, and spherical, and were easily observed (Fig. 1). Of 60 samples, 52 were determined to be Perkinsus positive, and the 8 remaining samples were deemed Perkinsus negative (Table 1).

\section{PCR and recombinant plasmid construction}

Electrophoresis of the PCR products revealed an approximate $673 \mathrm{bp}$ amplicon, shown in Fig. 2. 


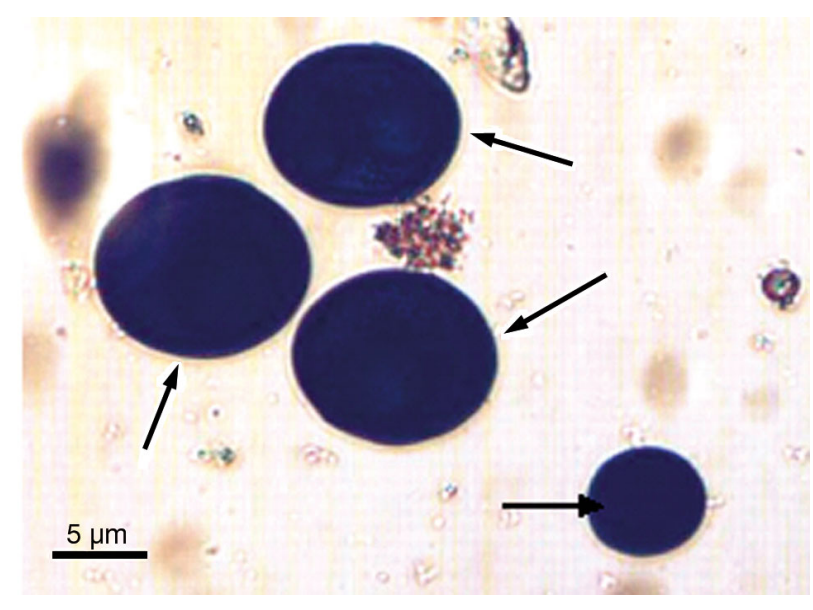

Fig. 1. Results of the RFTM assay. Arrows indicate the Lugol's iodine-dyed hypnospores of Perkinsus (100×)

Table 1. Diagnostic sensitivity and diagnostic specificity of the Perkinsus LAMP assay. Totals are given in parentheses. TP: true positive, FP: false positive, FN: false negative, TN: true negative

\begin{tabular}{|ccc|} 
Method & $\begin{array}{c}\text { RFTM positive } \\
(52)\end{array}$ & $\begin{array}{c}\text { RFTM negative } \\
(8)\end{array}$ \\
\hline LAMP positive (56) & $52(\mathrm{TP})$ & $4(\mathrm{FP})$ \\
LAMP negative (4) & $0(\mathrm{FN})$ & $4(\mathrm{TN})$ \\
\hline
\end{tabular}

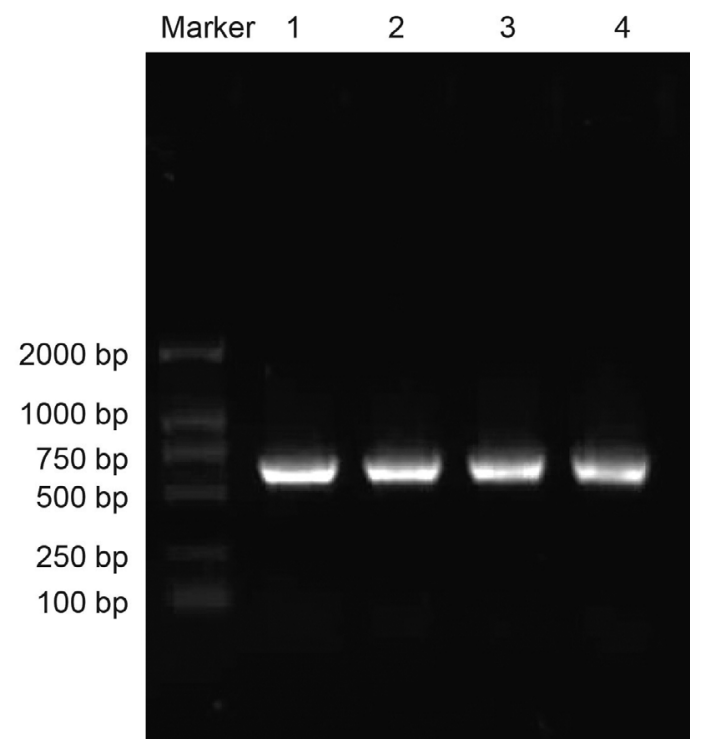

Fig. 2. Results of 4 representative Perkinsus olseni-infected clams Ruditapes philippinarum amplified by PCR assay. All 4 samples showed $673 \mathrm{bp}$ fragments as indicated. Lane 1, marker; lanes 2 to 5, PCR products from 4 clams
Sequencing results revealed that all PCR products were consistent with the targeted ITS2 sequence of Perkinsus olseni (GenBank accession number FJ841985).

\section{Optimization of Perkinsus LAMP assay}

Our experiment revealed that the concentration of some reagents can influence the efficiency of amplification. The optimal concentration of betaine and $\mathrm{Mg}^{2+}$ was $0.128 \mathrm{M}$ and $8 \mathrm{mM}$, respectively (Fig. 3A,B), whereas the concentration of dNTP, Bst DNA polymerase, and outer primers had little effect on the LAMP amplification efficiency. An increased concentration of the inner primer could improve amplification efficiency. Supplementation with loop primers could considerably speed up the reaction, as shown in Fig. 3C,D. The optimal reaction system (25 $\mu$ l volume) was thus $1 \times$ Thermo buffer, $0.128 \mathrm{M}$ betaine, $8 \mathrm{mM} \mathrm{MgSO}, 1 \mathrm{mM}$ dNTP mix, $8 \mathrm{U}$ Bst DNA polymerase, $0.2 \mu \mathrm{M}$ primer F3 and B3, $2 \mu \mathrm{M}$ primer FIP and BIP, $0.8 \mu \mathrm{M}$ primer LF and LB.

\section{Sensitivity and specificity of Perkinsus LAMP assay}

Our results indicated that the detection limit of the developed Perkinsus LAMP assay was 10 copies of plasmid DNA with loop primers. The detection time was $49.8 \mathrm{~min}$ (Fig. 3D). There was no amplification with one copy of plasmid template and the negative control within $90 \mathrm{~min}$. In the specificity test for the Perkinsus LAMP assay, DNA template from Bonamia ostreae, Ichthyophthirius multifiliis, Haplosporidium nelsoni and healthy clam tissue did not yield any positive result (Fig. 4). With the developed LAMP assay, 18 of 40 oyster samples were shown to be Perkinsus sp. positive, which was consistent with the results of PCR and histological identification for P. marinus.

\section{Evaluation of the Perkinsus LAMP assay}

Of 60 samples, 56 yielded a positive result in the LAMP assay (Table 1). These 56 samples included 52 positive and 4 negative samples as determined by RFTM. To confirm the infection status of the 4 samples which were negative by RFTM but positive by LAMP, amplified DNA of the 4 LAMP products was digested with the endonuclease EcoRI. All showed $87 \mathrm{bp}$ and $101 \mathrm{bp}$ fragments in electrophoresis, which was in agreement with the predicted fragment size 


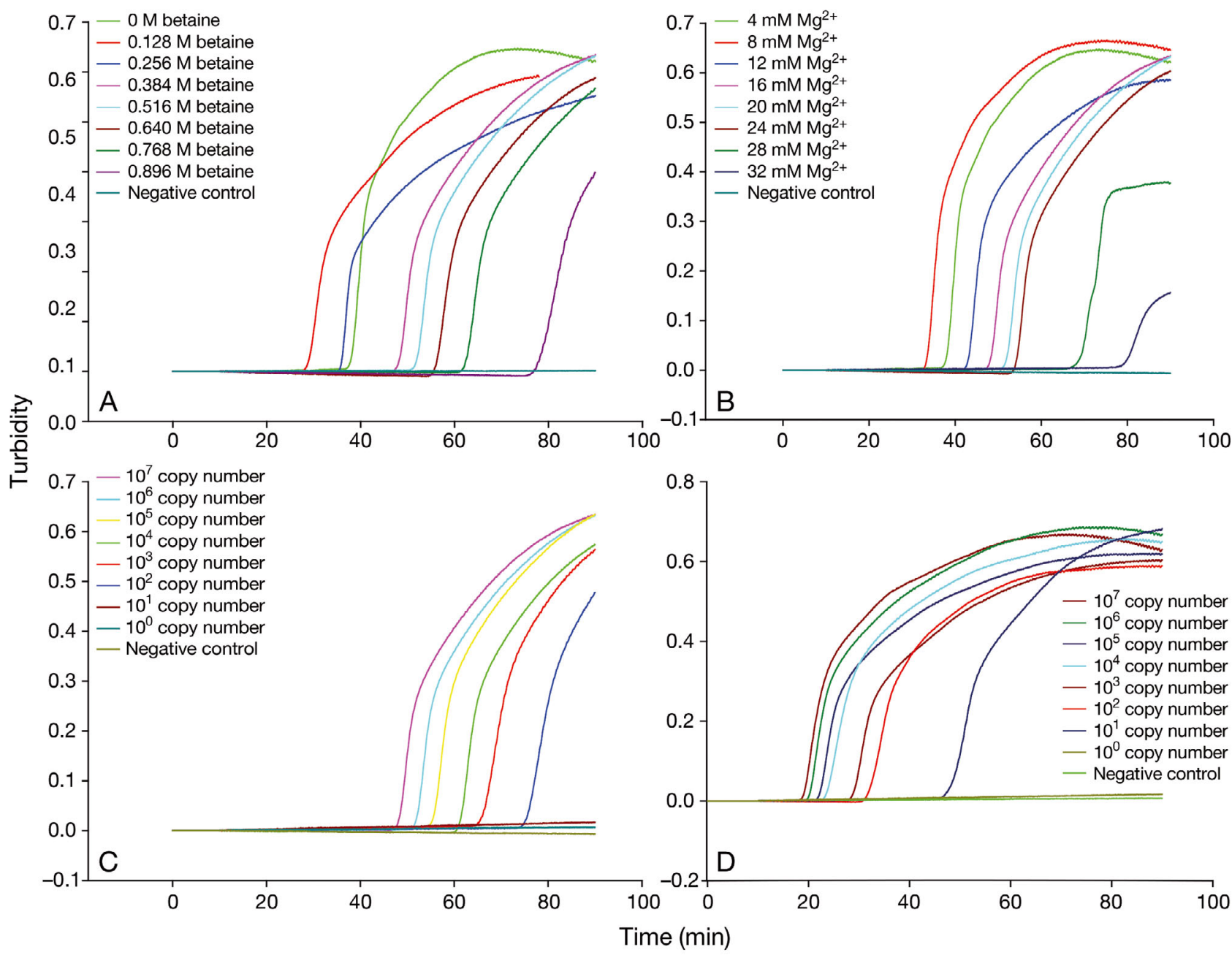

Fig. 3. Optimization of the LAMP reaction system: (A) betaine concentration; (B) $\mathrm{Mg}^{2+}$ concentration. (C) LAMP reaction without loop primers, and using 10 -fold serial dilutions of plasmids from $10^{7}$ to $10^{0}$ copies as templates; (D) LAMP reaction with loop primers, using the same templates as in panel C

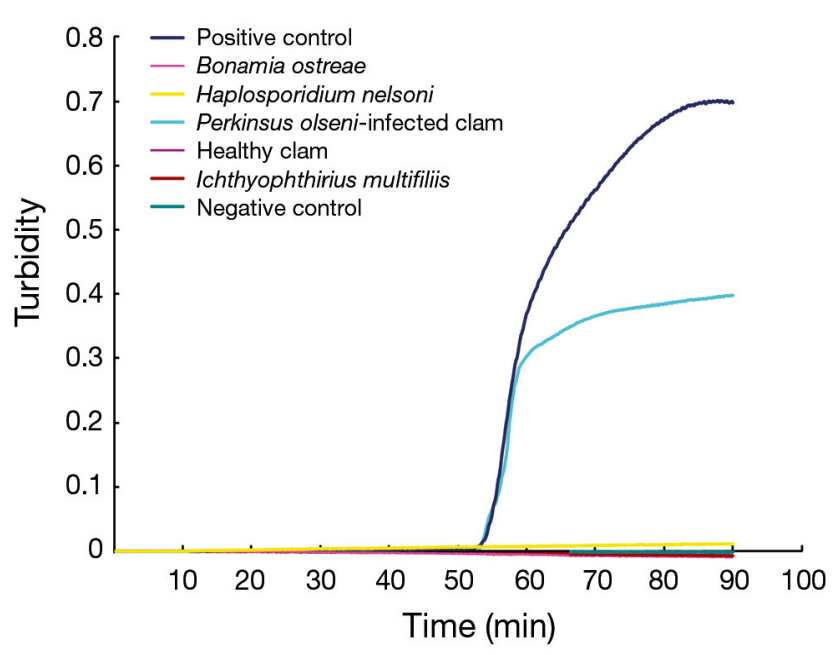

Fig. 4. Determination of the specificity of the Perkinsus LAMP assay
(Fig. 5). Further sequencing and BLAST of the digested products showed that all belonged to Perkinsus spp. Thus, the 4 RFTM-negative samples were in fact infected with Perkinsus. The DSe and DSp for the Perkinsus LAMP method were 100 and $50 \%$, respectively (Table 1 ).

\section{DISCUSSION}

Being responsible for mass mortality of some commercially valuable shellfish, Perkinsus has received much attention in recent years. The association of Perkinsus spp. with large mortalities has required detection methods for surveillance and quarantine in the field and at ports. The LAMP assay is known for its simplicity. The LAMP reaction can be carried out by mixing the template and reaction reagents in a single 


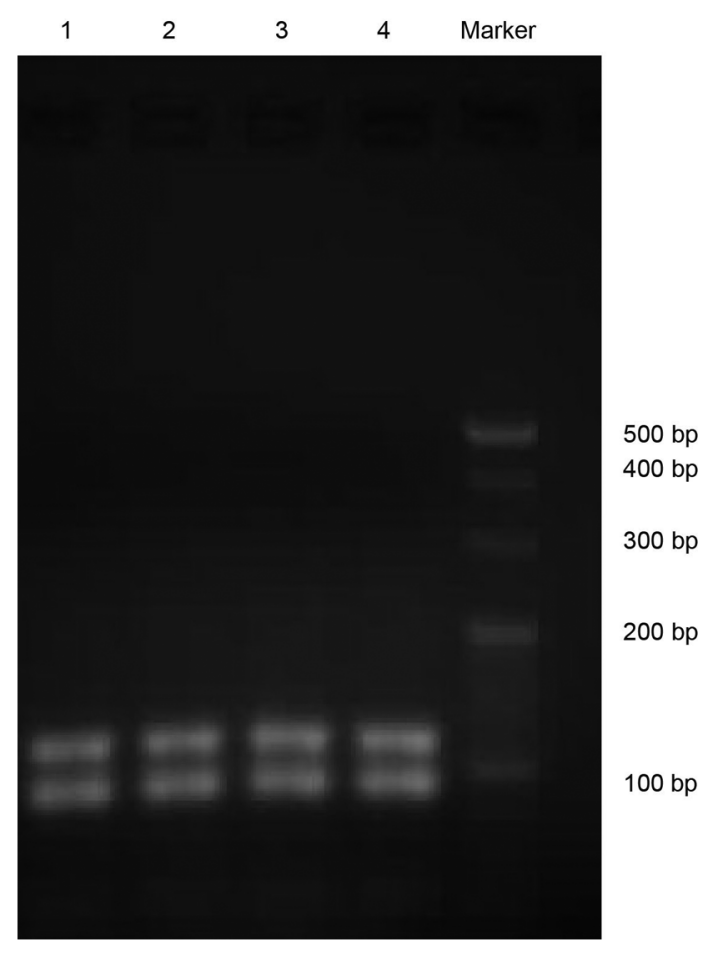

Fig. 5. Electrophoresis of endonuclease digestions of 4 LAMP products of LAMP-positive but RFTM-negative samples

tube and then incubating at stable $60-65^{\circ} \mathrm{C}$ for a short time. The only laboratory equipment needed for the LAMP reaction is a regular water bath or a heating block that can provide a constant temperature. With these considerations, a LAMP assay for the detection of Perkinsus spp. was developed in this study.

The primers for the LAMP assay were designed based on the ITS2 region of Perkinsus spp. ITS regions in the rRNA gene of the protozoan represent a domains that accumulate a high degree of sequence variability between genera but a relatively conserved region between species of Perkinsus, and are commonly used as gene markers (Kotob et al. 1999). The consistency and specificity of the primers were analyzed using BLAST online. The region amplified by our LAMP assay was $100 \%$ conserved between P. olseni, P. marinus, P. mediterraneus, and P. honshuensis, which indicated theoretically that this assay could be applied to detect several Perkinsus spp. In this study, we detected 2 OIE notifiable species of Perkinsus, viz. P. olseni, and P. marinus, by the LAMP assay. Due to the limited sample materials in our lab, more Perkinsus species should be tested in the future.

As indicated in our data, $\mathrm{Mg}^{2+}$ and betaine could affect the reaction efficiency (Fig. 3A,B). We used $8 \mathrm{mM}$ $\mathrm{Mg}^{2+}$ in our LAMP, which showed little difference with other reports, while $0.128 \mathrm{M}$ betaine was substantially lower compared to other reports (Gunimaladevi et al. 2005, Zhao et al. 2010). These results offer a new range of betaine concentration for future studies. The loop primers could also accelerate the amplification efficiency of the LAMP. The lowest detection limit of the LAMP assay was 100 copies without loop primers but improved to 10 copies with loop primers (Fig. 3C,D). The loop primers could hybridize with and help the formation of stem-loops, which greatly enhance the velocity of the LAMP reaction (Nagamine et al. 2002). Mori et al. (2001) showed that the DNA template could be increased up to $10^{9}$ times within 10 to $15 \mathrm{~min}$ when adding loop primers to the reaction solution. To enhance the reliability of the LAMP examination in the field, the gills of infected clams were selected as the material to extract DNA. Gills of infected clams have the highest concentration of Perkinsus, as reported by Alderman \& Gras (1969).

Given the short time for temperature changes during the reaction (Nagamine et al. 2001), the LAMP assay could be finished within $49.8 \mathrm{~min}$ in our study (Fig. 3D), which is faster than conventional PCR methods. This is very important for the quarantine at ports, where shorter times for import and export admission are necessary to ensure high quality of the goods.

No cross-reactivity to clam tissue itself and other aquatic parasites was observed for the LAMP assay (Fig. 4). This result is consistent with previous studies (Liu et al. 2008, Chen et al. 2010), and might be due to the use of a set of 6 primers targeting 8 distinct regions on template DNA and the selection of the properly targeted DNA region. Up until now, the LAMP assay has been extensively used in pathogen detection (Liu et al. 2008, Yamazaki et al. 2008, Chen et al. 2010).

The RFTM assay has been recommended as the 'gold standard,' but it only detects Perkinsus spp. from fresh host tissue. Combined with the DNA extaction method, the LAMP assay in this study could detect Perkinsus spp. from fresh or frozen tissues and environments like sea water and dirt, which the RFTM assay cannot (Audemard et al. 2004). The RFTM assay was reported to be only able to detect $>1000$ P. marinus cells per gram of wet oyster tissue (Bushek et al. 1994). As shown by our research data, the lowest detection limit of the LAMP assay was 10 copies of plasmid without considering that there are multiple regions of ITS2 in the genome of one Perkinsus cell, which was similar to real-time PCR (10 versus 26 plasmid copies; Wu et al. 2009). LAMP was also reported to be more sensitive than conventional 
PCR (Z. Liu et al. 2008, A. Liu et al. 2012). Other reports showed that the LAMP assay could detect a limit of 10 copies of the apical membrane antigen-1 (AMA-1) gene of parasitemia (Lau et al. 2011). The detection limit of the LAMP assay developed for the detection of Theileria luwenshuni and T. uilenbergi, parasites of small ruminants, was down to $0.1 \mathrm{pg}$ of parasite DNA (Liu et al. 2008).

Reclassification of 4 samples from RFTM by the LAMP assay showed that the LAMP assay was more sensitive than the RFTM assay in perkinsosis diagnosis, even though they had the same value of Dse when RFTM was selected as the 'gold standard.' For this reason, the Dsp of the LAMP assay was only $50 \%$ of that of the RFTM assay.

The LAMP also showed great potential for application in the field with or without special equipment. The white turbidity can be observed by the naked eye, and observations could be simplified by pulsespinning the precipitate into the bottom of the tube. Other methods for the convenient observation of LAMP products, such as dyeing with calcein (Tomita et al. 2008), SYBR Green, or HNB (Venkatesan et al. 2012) have also been developed as alternatives. Being a one-tube reaction, the LAMP assay minimizes potential environmental contamination, is convenient for detection on-scene and can potentially be used in quarantine/surveillance programs.

Acknowledgments. The project was supported by the National Natural Science Foundation of China (30972180) and the scientific project of AQSIQ (2012JK010, 201210018).

\section{LITERATURE CITED}

Alderman DJ, Gras P (1969) 'Gill disease' of Portuguese oysters. Nature 224:616-617

> Audemard C, Reece KS, Burreson EM (2004) Real-time PCR for detection and quantification of the parasite Perkinsus marinus in environmental waters. Appl Environ Microbiol 70:6611-6618

Bushek D, Ford SE, Allen SK Jr (1994) Evaluation of methods using Ray's fluid thioglycollate medium for diagnosis of Perkinsus marinus infection in the eastern oyster, Crassostrea virginica. Annu Rev Fish Dis 4:201-217

Bushek D, Dungan CF, Lewitus AJ (2002) Serological affinities of the oyster pathogen Perkinsus marinus (Apicomplexa) with some dinoflagellates (Dinophyceae). J Eukaryot Microbiol 49:11-16

> Casas SM, Villalba A, Reece KS (2002) Study of perkinsosis in the carpet shell clam Tapes decussatus in Galicia (NW Spain). I. Identification of the aetiological agent and in vitro modulation of zoosporulation by temperature and salinity. Dis Aquat Org 50:51-65

Chen L, Fan XZ, Wang Q, Xu L and others (2010) A novel RT-LAMP assay for rapid and simple detection of classical swine fever virus. Virol Sin 25:59-64
Choi KS, Wilson EA, Lewis DH, Powell EN, Ray SM (1989) The energetic cost of Perkinsus marinus parasitism in oysters: quantification of the thioglycollate method. J Shellfish Res 8:125-131

> Dungan CF, Roberson BS (1993) Binding specificities of mono- and polyclonal antibodies to the protozoan oyster pathogen Perkinsus marinus. Dis Aquat Org 15:9-22

Fukuta S, Mizukami Y, Ishida A, Ueda J and others (2004) Real-time loop mediated isothermal amplification for the CaMV-35S promoter as a screening method for genetically modified organisms. Eur Food Res Technol 218: 496-500

Gunimaladevi I, Kono T, LaPatra SE, Sakai M (2005) A loopmediated isothermal amplification (LAMP) method for detection of infectious hematopoietic necrosis virus (IHNV) in rainbow trout (Oncorhynchus mykiss). Arch Virol 150:899-909

> Hirayama H, Kageyama S, Moriyasu S, Sawai K and others (2004) Rapid sexing of bovine preimplantation embryos using loop-mediated isothermal amplification. Teriogenology 62:887-896

Horibe D, Ochiai T, Shimada H, Tomonaga T and others (2007) Rapid detection of metastasis of gastric cancer using reverse transcription loop-mediated isothermal amplification. Int J Cancer 120:1063-1069

Kotob SI, McLaughlin SM, Van Berkum P, Faisal M (1999) Discrimination between two Perkinsus spp. isolated from the softshell clam, Mya arenaria, by sequence analysis of two internal transcribed spacer regions and the 5.8s ribosomal RNA gene. Parasitology 119:363-368

Lau YL, Fong MY, Mahmud R, Chang PY and others (2011) Specific, sensitive and rapid detection of human Plasmodium knowlesi infection by loop-mediated isothermal amplification (LAMP) in blood samples. Malar J 10:197

> Liu A, Guan G, Du P, Gou H and others (2012) Loop-mediated isothermal amplification (LAMP) method based on two species-specific primer sets for the rapid identification of Chinese Babesia bovis and B. bigemina. Parasitol Int 61:658-663

> Liu Z, Hou J, Bakheit MA, Salih DA and others (2008) Development of loop-mediated isothermal amplification (LAMP) assay for rapid diagnosis of ovine theileriosis in China. Parasitol Res 103:1407-1412

Mori Y, Nagamine K, Tomita N, Notomi T (2001) Detection of loop-mediated isothermal amplification reaction by turbidity derived from magnesium pyrophosphate formation. Biochem Biophys Res Commun 289:150-154

> Nagamine K, Watanabe K, Ohtsuka K, Hase T, Notomi T (2001) Loop-mediated isothermal amplification reaction using a nondenatured template. Clin Chem 47: 1742-1743

> Nagamine K, Hase T, Notomi T (2002) Accelerated reaction by loop-mediated isothermal amplification using loop primers. Mol Cell Probes 16:223-229

Notomi T, Okayama H, Masubuchi H, Yonekawa T, Watanabe $K$, Amino N, Hase T (2000) Loop-mediated isothermal amplification of DNA. Nucleic Acids Res 28:E63

OIE (World Organization of Animal Health) (2012a) OIE manual of diagnostic tests for aquatic animals. OIE, Paris

OIE (World Organization of Animal Health) (2012b) OIE terrestrial manual. OIE, Paris

> Park KI, Park JK, Lee J, Choi KS (2005) Use of molecular markers for species identification of Korean Perkinsus sp. isolated from Manila clams Ruditapes philippinarum. Dis Aquat Org 66:255-263 
Ray SM (1952) A culture technique for the diagnosis of infections with Dermocystidium marinum Mackin, Owen, and Collier, in oysters. Science 116:360-361

Robledo JAF, Gauthier JD, Coss CA, Wright AC, Vasta GR (1998) Species-specificity and sensitivity of a PCR-based assay for Perkinsus marinus in the eastern oyster, Crassostrea virginica: a comparison with the fluid thioglycollate assay. J Parasitol 84:1237-1244

Tatibana BT, Sano A, Uno J, Kamei K and others (2009) Detection of Paracoccidioides brasiliensis gp43 gene in sputa by loop-mediated isothermal amplification method. J Clin Lab Anal 23:139-143

Tomita N, Mori Y, Kanda H, Notomi T (2008) Loop-mediated isothermal amplification (LAMP) of gene sequences and simple visual detection of products. Nat Protoc 3: 877-882

- Venkatesan G, Bhanuprakash V, Balamurugan V, Singh RK, Pandey AB (2012) Development of loop-mediated isothermal amplification assay for specific and rapid detection of camelpox virus in clinical samples. J Virol Methods 183:34-39

Villalba A, Reece KS, Camino Ordás M, Casas SM, Figueras

Editorial responsibility: Mike Hine,

Fouras, France
A (2004) Perkinsosis in molluscs: a review. Aquat Living Resour 17:411-432

Wu SQ, Li HY, Lin XM, Zheng T and others (2009) Establishment and application of real time PCR method for detection of Perkinsus sp. in bivalves. Prog Fish Sci 30:58-63 (in Chinese with English summary)

> Wu S, Wang C, Lin X, Wang Z and others (2011) Infection prevalence and phylogenetic analysis of Perkinsus olseni in Ruditapes philippinarum from East China. Dis Aquat Org 96:55-60

Yamazaki W, Ishibashi M, Kawahara R, Inoue K (2008) Development of a loop-mediated isothermal amplification assay for sensitive and rapid detection of Vibrio parahaemolyticus. BMC Microbiol 8:163

Yarnall HA, Reece KS, Stokes NA, Burreson EM (2000) A quantitative competitive polymerase chain reaction assay for the oyster pathogen Perkinsus marinus. J Parasitol 86:827-837

Zhao X, Li Y, Wang L, You L and others (2010) Development and application of a loop-mediated isothermal amplification method on rapid detection Escherichia coli O157 strains from food samples. Mol Biol Rep 37:2183-2188

Submitted: July 23, 2012; Accepted: February 21, 2013

Proofs received from author(s): April 25, 2013 